\title{
Development of Instructional Module Based on Inquiry-Interactive Demonstration to Improve Students' Critical Thinking Skills
}

\author{
Itsna Yunida Al Husna ${ }^{1}$, Mohammad Masykuri ${ }^{2}$, Muzzazinah ${ }^{3}$ \\ Universitas Sebelas Maret, Indonesia ${ }^{1,2,3}$ \\ itsna.yunida@gmail.com¹, mmasykuri@staff.uns.ac.id ${ }^{2}$, yayin_pbio@fkip.uns.ac.id ${ }^{3}$
}

Received: July $12^{\text {th }}$, 2020. Revised: September $10^{\text {th }}, 2020$. Accepted: October $12^{\text {th }}, 2020$

\author{
Keywords : \\ Instructional Module; \\ Interactive Demonstration; \\ Critical Thinking Skill; \\ Science Learning; \\ Junior High School
}

\begin{abstract}
This research was a research and development $(R \& D)$ that produced products in the form of learning modules. The purpose of this research are to find out: (1) The characteristics of the material classification and its changes instructional module; (2) The feasibility of the material classification and its changes instructional module; (3) The instructional module effectiveness in increasing critical thinking skills. The procedure of this research are: (1) preliminary research \& information gathering; (2) planning (3) initial product development; (4) initial field trial; (5) major product revisions; (6) main field test; (7) operational product revisions; (8) operational field test; (9) final product revision. The results of research and development show: (1) the characteristics of the instructional module as learning objects in accordance with the inquiry-interactive demonstration learning on the classification material and its changes; (2) instructional module eligibility based on experts assessment, education practitioners, and students produces $81.74 \%$ achievement with very good qualifications; (3) module as learning objects resulting from the development are effective in improving students' critical thinking skills with an $\mathrm{N}$-Gain score of 0.561 .
\end{abstract}

\section{INTRODUCTION}

The chapter of classification of material and its changes is one of the topics of science that has a low absorption based on the results of the 2018 National Examination. The low acquisition on that topic is caused by the characteristics of the material. The characteristics of the science topic consist of concepts that represent three levels of representation, namely macroscopic, submicroscopic, and symbolic. Macroscopic representations are concepts that students can learn through observations of phenomena that can be seen and felt by the senses and experiences experienced by students in daily life [1]. Subtopic of microscopic representations are concepts that provide explanations at the level of particulates which are not directly observable by the human senses [2]. Symbolic representation is a concept symbolized in symbols, graphs, formulas, and equations [2]. 
The studies before show the low understanding of students in macroscopic representations, the existence of concept misconceptions in submicroscopic representations, and the lack of students' understanding of complexity as outlined in symbolic representations [3]. Students have difficulty in macroscopic representation when faced with a concept that has never been experienced before [4]. Understanding sub-microscopic concepts is considered difficult and abstract so that it is considered to study things that have no meaning [4] [5]. Understanding of symbolic representations is considered difficult when students make connections between symbols, structures, and chemical processes [6]. the topic of material classification and its changes contains concepts at the sub-microscopic level that require students to think critically and analytically [7]. To overcome these problems one of them can be done by learning to use module as learning objects. module as learning objects are a set of teaching materials that are arranged systematically and function as independent teaching materials, substitute for educator functions, evaluation tools, and as reference material for students [8] [9].

Module as learning objects as teaching materials are independent, placing students as learners in improving their ability to think independently. module as learning objects as a substitute for the function of educators, are arranged systematically and easily understood by students in which there are learning materials and learning activities that are tailored to the level of knowledge. module as learning objects as evaluation tools, allow students to know the extent of their understanding of the material being studied. module as learning objects as reference material, facilitate students in finding references in understanding concepts at the level of macroscopic, sub-microscopic, and symbolic representations that can be accounted for accuracy.

In addition to topics / teaching materials, module as learning objects must reflect approaches and objectives or competencies that are appropriate to the level of student knowledge [10]. The purpose of developing module as learning objects is one of them as a means of training students' thinking skills. Indonesia has been implementing 2013 curriculum at school at this time. The 2013 curriculum demand 21st Century skills include communication, collaboration, critical thinking and problem solving, and creativity, to have by students. 21st Century skills is the key of student successes in personal, social, academic, and professional not only national but also international scale [11].

One of the 21st century skills is critical thinking which is becoming an important issue in learning [12] as personal competence to confront competition in the future [13]. Critical thinking is an ability and skill [14] require reflective thinking process [12] [15] in analysis and evaluate an information [16]. Critical thinking involve complex process which needed high cognitive [16]. A critical thinking skill of student is needed to improve [17] because the critical thinker ones is more needed in the world of work [18].

The important of critical thinking skill for student, so needed to empowerment by using instructional module in learning process. The empowerment of critical thinking skills is made explicit in the material classification and its changes instructional module. The material classification and its changes instructional module use a scientific approach on the basis of the inquiry-interactive demonstration learning model. Inquiry-interactive demonstration is one of the levels of inquiry learning according to Wenning [19]. Interactive Demonstration is a student-centered learning model. Students are asked to predict the results of experiments, observe, and discuss predictions that have been made [20]. The use of Interactive Demonstration as a base model in the instructional module with regard to student conditions and development. Based on observations, students still depend on the guidance and guidance of teachers in learning. Level of inquiry - Interactive Demonstration which is the lowest level of inquiry learning after discovery learning. Interactive demonstration helps students learn better and more easily in understanding concepts they find difficult [21]. The use of interactive demonstration in the model base on the developed instructional module is expected to be able to train students' critical thinking skills on the topic of material classification and its changes in accordance with the conditions and development of students. 
Development of Instructional Module Based on Inquiry-Interactive Demonstration... Itsna Yunida Al Husna, Mohammad Masykuri, Muzzazinah

\section{METHOD}

This type of research and development (R\&D) refers to the design of the Borg \& Gall model [22]. The design model consists of ten stages, but only limited to the ninth stage, which consists of; (1) preliminary research \& information gathering; (2) planning; (3) initial product development; (4) initial field trial; (5) major product revisions; (6) main field test; (7) operational product revisions; (8) operational field test; (9) final product revision.

The feasibility of the instructional module is analysed based on the results of the validation at the initial field test stage by expert validators who are expert lecturers including: material, learning, media, and language experts. Furthermore, the initial field test was carried out by education practitioners namely science teachers and state junior high school students in Surakarta. Qualitative data in the form of suggestions, input, and responses by experts, education practitioners, and students were analysed descriptively qualitatively. Quantitative data obtained from assessments by experts, education practitioners, and students were analysed descriptively qualitatively.

The instructional module implementation phase is in the operational field trials carried out by conducting learning using modul as learning objects with the subject used is student of VII A and VII B class in SMP Negeri 20 Surakarta school year 2019/2020. Implementing modul as learning objects in the classroom to find out the improvement of students' critical thinking skills using pretest and postest design [23]. The design of the chosen research method can be seen in Table 1.

Table 1. Research Design [24]

\begin{tabular}{ccc}
\hline Class & Treatment & Pretest \& Posttest \\
\hline Experiment (E) & $\mathrm{X}_{1}$ & $\mathrm{O}_{1}$ \\
Control (C) & $\mathrm{X}_{2}$ & $\mathrm{O}_{1}$ \\
\hline
\end{tabular}

Information:

$\mathrm{X}_{1} \quad$ : Treatment using instructional module

$\mathrm{X}_{2} \quad$ : Treatment using learning book of school

$\mathrm{O}_{1} \quad$ : Pretest \& posttest critical thinking questions for experiment and control class

Students of experiment and control class are given six items of critical thinking questions. The type of question is essay test according to six indicators of critical thinking skill by Facione. The test is given before (pretest) and after (posttest) student learned classification of material and its changes topics. Then the gain of pretest and posttest score analysed. The analysis used to determine the increase (gain) of critical thinking skills is the Gain score. The gain score is also called the increase or difference in scores which is the difference between the pretest and post-test scores in one sample group. The gain score can be obtained using the following formula according to Meltzer [25]:

$$
N-\text { Gain }=\frac{T \text { post }-T_{\text {pre }}}{T_{\text {maks }}-T_{\text {pre }}}
$$

Information:

$\mathrm{T}_{\text {post }} \quad$ : Mean score of post-test

$\mathrm{T}_{\text {pre }} \quad$ : Mean score of pretest

$\mathrm{T}_{\text {maks }}$ : Maximum score

Table 2. Category of N-Gain Score

\begin{tabular}{cc}
\hline $\mathbf{N}-$ Gain $(\mathrm{g})$ & Category \\
\hline$(\mathrm{g}) \geq 0.7$ & High \\
$0,3<(\mathrm{g}) \leq 0.7$ & Medium \\
$(\mathrm{g}) \leq 0.3$ & Low \\
\hline
\end{tabular}


The gain score obtained from the formula above can be analyzed by category using the gain score interpretation table according to the Table 2. The basis for decision making is that the resulting development instructional module is considered effective in improving critical thinking skills if $\mathrm{N}$-gain is included in the medium category, the value $<\mathrm{g}>$ ranges from $0.3<(\mathrm{g}) \leq 0.7$.

\section{RESULTS AND DISCUSSIONS}

\section{Characteristics of the Instructional Modul}

The characteristics of the modul as learning objects developed are modul as learning objects integrated with inquiry-interactive demonstration learning to make students think actively and be involved in the discovery process. This is relevant to the theory of constructivism in which students are actively involved in finding the understanding they want to know [26]. The material classification and its changes instructional module based on the Inquiry-Interactive Demonstration model to improve critical thinking skills have the following characteristics: (1) learning steps that are explicitly included in the module; (2) contains a description of the material in accordance with BC 3.3 and 4.3; (3) discovery-based learning to develop student knowledge; (4) there are practice questions and student activities to develop students' critical thinking skills; (5) accommodate student to understanding representation level concept of macroscopic, sub-microscopic, and symbolic.

Interactive demonstration as the basis learning model of interactional module consists of five stages, observation, manipulation, generalization, verification, and application which are explicitly included in the module. The observation stage in the module invites students to identify the demonstrations/ phenomena that are presented and then students are asked to formulate problems and make hypotheses. The manipulation stage in the module consists of science experiments to prove the hypotheses that have been written by students. The generalization stage in the module consists of student questions discussion related to the experiment as well as group discussion conclusions. The verification stage in the module asks students to compare the results with other groups to find out the truth of the hypothesis that has been made and to make conclusions. The application stage in the module asks students to apply their knowledge to new problems that are presented with questions based on indicators of critical thinking.

Module contain simple science experiments to understanding macroscopic concepts not only by reading reference, but also directly practicing. Sub-microscopic representation concept is explained in module by visualizing the abstract concept and giving student exercise. Giving the related images can help student convey the information being learned and strengthen memory by impressing the reader with images. Symbolic representation concept is explained in module by giving connection symbol with the concept, how to use formulas to the concepts, how to relate them in daily concepts, and student exercise.

The development of module has result module for student and learning guidelines for teacher. Module for student has contain student activity based on Inquiry-Interactive Demonstration, questions based on critical thinking indicators, and explanation of the chapter of classification of material and its changes. Learning guidelines for teacher has contain syllabus, lesson plan, assessment instruction, and key of answer.

\section{Validation Results}

The validation results were obtained at the initial field test stage by the material, learning, media and language experts. The input results and suggestions obtained at this stage are used to improve the instructional module. Then the module will conduct a major field test to find out suggestions and input by education practitioners and students. The recapitulation of the results of the assessment by experts, education practitioners, and students is presented in Table 3. 
Development of Instructional Module Based on Inquiry-Interactive Demonstration... Itsna Yunida Al Husna, Mohammad Masykuri, Muzzazinah

Table 3. Validation Results

\begin{tabular}{|c|c|c|c|c|}
\hline Rater & $\begin{array}{c}\text { Score in } \\
\text { Percentage } \\
(\%)\end{array}$ & $\begin{array}{l}\text { Qualifi- } \\
\text { cation }\end{array}$ & Decision & Comments \\
\hline $\begin{array}{l}\text { Material } \\
\text { experts }\end{array}$ & 78.13 & Good & $\begin{array}{l}\text { Qualified } \\
\text { to use with } \\
\text { major } \\
\text { revision as } \\
\text { suggested }\end{array}$ & $\begin{array}{l}\text { 1. Images are not very suitable to the } \\
\text { chapter used in the modul } \\
\text { development } \\
\text { 2. Few of chemist equation are not set } \\
\text { to be clear as the index are not used } \\
\text { properly }\end{array}$ \\
\hline $\begin{array}{l}\text { Teaching and } \\
\text { learning } \\
\text { experts }\end{array}$ & 70,83 & Good & $\begin{array}{l}\text { Qualified } \\
\text { to use with } \\
\text { major } \\
\text { revision as } \\
\text { suggested }\end{array}$ & $\begin{array}{l}\text { 1. The aim of learning from modul is } \\
\text { not set as ABCD method (goal, } \\
\text { subjects, instrument, manner of } \\
\text { students) } \\
\text { 2. Concept map don't use any } \\
\text { conjunction } \\
\text { 3. In the learning instruction using } \\
\text { modul: it is necessary to add } \\
\text { component of learning model (the } \\
\text { influence of social aspect, } \\
\text { instructional aspect, and additional } \\
\text { aspect) }\end{array}$ \\
\hline Media experts & 82.49 & Very good & $\begin{array}{l}\text { Qualified } \\
\text { to use with } \\
\text { minor } \\
\text { revision as } \\
\text { suggested }\end{array}$ & $\begin{array}{l}\text { 1. There is no references of cover } \\
\text { image } \\
\text { 2. Inconsistent space as punctuation } \\
\text { 3. Inconsistent font size } \\
\text { 4. Low resolution picture }\end{array}$ \\
\hline $\begin{array}{l}\text { Language } \\
\text { experts }\end{array}$ & 83.33 & Very good & $\begin{array}{l}\text { Qualified } \\
\text { to use with } \\
\text { minor } \\
\text { revision as } \\
\text { suggested }\end{array}$ & $\begin{array}{l}\text { 1. Ineffective sentence } \\
\text { 2. Incorrect use of punctuation }\end{array}$ \\
\hline Teacher & 86.54 & Very good & $\begin{array}{l}\text { Qualified } \\
\text { to use with } \\
\text { minor } \\
\text { revision as } \\
\text { suggested }\end{array}$ & $\begin{array}{l}\text { 1. Fluids to be revised as color fluid to } \\
\text { specify the question } \\
\text { 2. Tin to be revised as bottle to make a } \\
\text { clear imagery of experiment }\end{array}$ \\
\hline Student & 90.60 & Very good & - & $\begin{array}{l}\text { 1. Text is unclear } \\
\text { 2. Low resolution picture }\end{array}$ \\
\hline
\end{tabular}

The instructional module were declared feasible after the material, learning, media and language feasibility tests were carried out at the initial field trial stage. The feasibility of the material / content is assessed from the suitability of the material with the core competencies (KI) and basic competencies $(\mathrm{KD})$, the accuracy of the material, and the suitability of the learning support material [27]. The feasibility of the media in the form of graphics / display modul as learning objects is intended to convey messages (informative), persuasive, even commercial [28]. Language worthiness is assessed based on language suitability, conformity with the level of students' intellectual development, communicative and logic [27]. Eligibility in terms of learning is assessed based on the suitability of the learning model that is used as a base module to facilitate students in learning independence [29]. The initial field trial by the expert validators of materials, learning, media, and language resulted in a module eligibility of $78.33 \%$ with good qualifications. The evaluation by the expert validators shows that the module is eligible for field trials with revisions as suggested.

The main field trial was readability assessment by education practitioners namely science teachers and 
small group tests where students produced $88.57 \%$ eligibility with very good qualifications. These results indicate that the module meets the learning criteria. Based on recapitulation of the results of the assessment by expert validators, education practitioners, and students on the material classification module and the changes obtained an average level of achievement of $81.74 \%$ with very good qualifications. The resulting development module is ready for operational/ implementation field testing after the module has been revised according to suggestions and comments. The final result of module development is as follows.

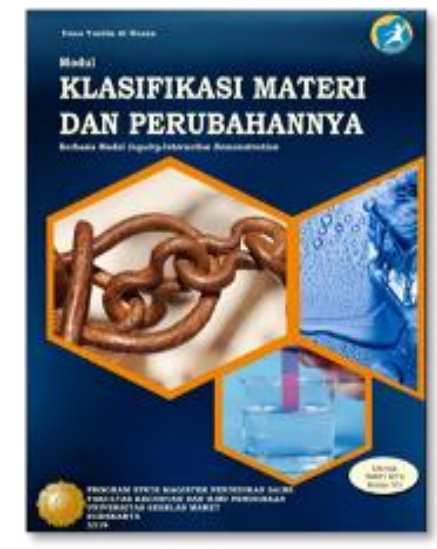

(a)

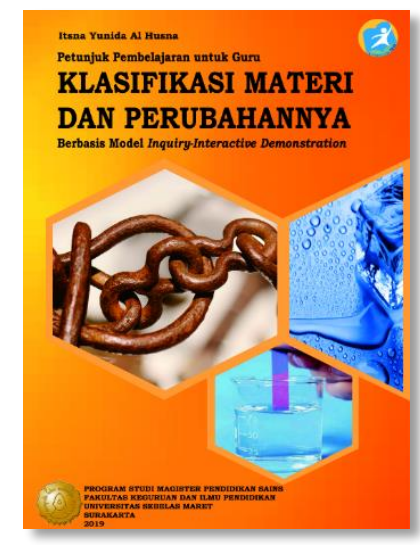

(b)

Fig 1. The Overview of Development Results Modules: (a) Module for Student; (b) Learning Guidelines for Teacher

The Effectiveness of Instructional Module in Increasing Critical Thinking Skills

Implementation is done by $\mathrm{N}$-Gain score of student between experiment class (using instructional module in learning) and control class (using school book). Before learning, students are given a pretest that aims to determine the initial abilities of students before using modul as learning objects. Furthermore, students are given a post-test to see an increase in critical thinking skills after learning using modul as learning objects. The pretest and post-test questions given are 6 items of critical thinking essay questions with indicators of interpretation, inference, explanation, analysis, evaluation, and self regulation [12] that have been validated by experts. The questions contain concepts on the topic of classification of material and its changes related to students' daily lives. Analysis of the results of the module implementation of students' critical thinking skills is presented in Table 4.

Table 4. Pretest, Post-test and N-Gain Data

\begin{tabular}{cccccc}
\hline Class & $\mathbf{N}$ & $\overline{\boldsymbol{x}}$ Pretest & $\overline{\boldsymbol{x}}$ Posttest & N-Gain & Category \\
\hline Experiment & 30 & 29.032 & 59.677 & 0.427 & Medium \\
Control & 30 & 31.720 & 46.237 & 0.212 & Low \\
\hline
\end{tabular}

The result of analysis show that using instructional module in experiment class effective to improve critical thinking skill with category of N-Gain score medium, than control class have low category of $\mathrm{N}$-Gain score. Accordance to previously research show that using instructional module base on interactive demonstration model afford to improve critical thinking skill [30] and analytic skill [31].

The result of improvement student critical thinking skill is influence of learning model base that used in instructional module. Inquiry-interactive demonstration learning is one of the student-centered constructivist learning. It consists of steps of observation, manipulation, generalization, verification, and applications that make students actively and more independent in learning. Through interactive demonstration learning, students are directly involved in constructing knowledge based on direct experience when experimenting. The direct involvement of students in learning can improve learning outcomes and thinking skills [32]. Various studies have shown that the use of inquiry-interactive demonstration models can improve learning outcomes [33], problem solving skill [34], high order 
Development of Instructional Module Based on Inquiry-Interactive Demonstration... Itsna Yunida Al Husna, Mohammad Masykuri, Muzzazinah

thinking skill [23], and reduce student misconception [35]. Furthermore, the effectivity of using instructional module seen by $\mathrm{N}$-Gain score result in each indicators of critical thinking skill. The result of analysis each indicators are shown in Table 5.

Table 5. Analysis Result of Each Indicators Critical Thinking Skill

\begin{tabular}{ccccc}
\hline Indikator & Pretest & Posttest & N-Gain & Category \\
\hline Interpretation & 31.452 & 34.677 & 0.047 & Low \\
Inference & 27.419 & 87.097 & 0.822 & High \\
Evaluation & 22.581 & 72.581 & 0.646 & Medium \\
Analysis & 25.806 & 44.355 & 0.250 & Low \\
Explanation & 46.774 & 59.677 & 0.242 & Low \\
self-regulation & 20.161 & 59.677 & 0.495 & Medium \\
\hline
\end{tabular}

This result show the excess of instructional module effectively enhance inference, evaluation and selfregulation indicators and the lack of this instructional module cant effectively enhance interpretation, analysis, and explanation indicators. Inference is a person's ability to identify elements that are useful for making reasonable conclusions [12]. The ability to inference is the basis of a high-level thinking process that can be influenced by several factors namely background knowledge, interest, reading ability, and practice [36] [37] [38]. The use of this module can enhance inference indicator with the highest $\mathrm{N}$-gain score achievement. This indicate that learning with the instructional module can make student interest to reading and understanding the topic, doing the practice to answer questions on, so it will make student's skill to giving reasonable conclution be trained. Evaluation is credibility of statements that are descriptions of a persons' perception, experience, judgment, or opinion to assess the logical strength of descriptions, representation, etc [12]. Self-regulation is a self consciously to monitor one's cognitive activities, understanding or comprehending personal opinions and assumptions, and revise answers in view of errors [12].

Using instructional module is oneness inquiry-interactive demonstration learning. With the result that low achievement category of N-Gain score interpretation, analysis, and explanation indicators can be related by learning process that has been done. The low achievement of interpretation indicator due to generalization step, students' haven't been able to give meaning of result from observation to describe on observation table. The solution is give information clarify about table observation filling of student worksheet on module. The low achievement of analysis indicator due to demonstration giving not maximal enough make students' discover a problem in observation step. Student are required to use sensory, intelligence, and a ready hearth to understand and discover problem based on demonstration. Less involved students' to discover a problem make analysis skill can not be improved [39]. The low achievement of explanation indicator on verification and application steps due to student are not confident to explain their opinion orally and writing. Another cause is the lack of students' practice exercises related indicators. The exercises can make student trained to think and reason. Accordance to study before, train self to practice exercises on context intensively improve student's critical thinking skill [40].

The material classification and its changes module based on inquiry-interactive demonstration are modul as learning objects that facilitate students in understanding three levels of representation (macroscopic, submicroscopic, and symbolic). Aside from being a reference material, the results of this development module are able to train students' critical thinking skills. Students are encouraged to analyze, evaluate, make arguments, and make conclusions through activities and application questions in the module. Through these activities students will have a meaningful science learning experience. Inquiry learning integrated with modul as learning objects makes student learning experiences more meaningful and students are actively involved in the learning process [41]. 


\section{CONCLUSION AND SUGGESTION}

The conclusions of this research and development are: (1) the characteristics of the module developed based on inquiry-interactive demonstration learning on the topic of material classification and its changes in accordance with K.D. 3.3. and 4.3. for class VII students; 2) The feasibility of the development module has been tested through expert validation, education practitioner validation, small group test and operational field test resulting in module eligibility of $81.74 \%$ with very good qualifications; 3) modul as learning objects resulting from the development are effective in increasing students' critical thinking skills on material classification material and their changes with $\mathrm{N}$-Gain scores in the range of $0.3<(\mathrm{g}) \leq 0.7$. This research implies that the use of this instructional module is needed in science learning. Considering the conclusions drawn above, it implies that use of instructional module based on inquiry-interactive demonstration learning on the topic of material classification and its changes is capable to promote students' critical thinking skill. Students' critical thinking skill can be improved variously, it is expected that the future researcher can develop this study with consideration of different ways.

\section{REFERENCES}

[1] Treagust, D., Chittleborough, G., \& Mamiala, T. (2003). The role of submicroscopic and symbolic representations in chemical explanations. International Journal of Science Education, 25(11): 1353-1368.

[2] Wu, H. K., \& Shah, P. (2004). Exploring visuospatial thinking in chemistry learning. Science education, 88(3): 465-492.

[3] Gilbert, J. K., \& Treagust, D. F. (2009). Towards a coherent model for macro, submicro and symbolic representations in chemical education. In Multiple representations in chemical education (pp. 333-350). Springer, Dordrecht.

[4] Al-Balushi, S. M. (2013). The effect of different textual narrations on students' explanations at the submicroscopic level in chemistry. Eurasia Journal of Mathematics, Science and Technology Education, 9(1): 3-10.

[5] Tien, L. T., Teichert, M. A., \& Rickey, D. (2007). Effectiveness of a MORE laboratory module in prompting students to revise their molecular-level ideas about solutions. Journal of Chemical Education, 84(1): 175.

[6] Chandrasegaran, A. L., Treagust, D. F., \& Mocerino, M. (2008). An evaluation of a teaching intervention to promote students' ability to use multiple levels of representation when describing and explaining chemical reactions. Research in Science Education, 38(2): 237-248.

[7] Al Husna, I. Y., Masykuri, M., \& Muzzazinah, M. (2020). An Analysis of Low-Mastery Learning in Science National Examination 2018 and Its Strategies. In Proceedings of the 2nd International Conference on Education, ICE 2019, no. 23, pp. 689-698.

[8] Depdiknas. (2008). Teknik Penyusunan Modul. Jakarta: Direktorat Jendara Manajemen Pendidikan Dasar dan Menengah.

[9] Prastowo, A. (2012). Panduan Kreatif Membuat Bahan Ajar Inovatif. Yogyakarta: Diva Press.

[10] Nindiasari, H. (2011). Pengembangan Bahan Ajar Dan Instrumen Untuk Meningkatkan Berpikir Reflektif Matematis Berbasis Pendekatan Metakognitif Pada Siswa Sekolah Menengah Atas (SMA). In Semin. Nas. Mat. dan Pendidik. Mat. FMIPA UNY, pp. 251-263.

[11] Tican, C., \& Deniz, S. (2019). Pre-Service Teachers' Opinions about the Use of 21st Century Learner and 21st Century Teacher Skills. European Journal of Educational Research, 8(1): 181197.

[12] Facione, P. A. (2011). Critical thinking: What it is and why it counts. Insight assessment, 2007(1): $1-23$.

[13] P21. (2015). Framework for 21st Century Learning. [Online]. Available: https://www.battelleforkids.org. [Accessed: 17-Feb-2020].

[14] Elder, L., \& Paul, R. (1997). Critical thinking: Crucial distinctions for questioning. Journal of Developmental Education, 21(2): 34. 
Development of Instructional Module Based on Inquiry-Interactive Demonstration... Itsna Yunida Al Husna, Mohammad Masykuri, Muzzazinah

[15] Ennis, R. H. (2018). Critical thinking across the curriculum: A vision. Topoi, 37(1): 165-184.

[16] Duron, R., Limbach, B., \& Waugh, W. (2006). Critical thinking framework for any discipline. International Journal of Teaching and Learning in Higher Education, 17(2): 160-166.

[17] Kalelioglu, F., \& Gülbahar, Y. (2014). The Effect of Instructional Techniques on Critical Thinking and Critical Thinking Dispositions in Online Discussion. Educational Technology \& Society, 17(1): 248-258.

[18] Zubaidah, S. (2016, December). Keterampilan abad ke-21: Keterampilan yang diajarkan melalui pembelajaran. In Seminar Nasional Pendidikan dengan Tema "isu-isu strategis pembelajaran MIPA Abad (Vol. 21, No. 10).

[19] Wenning, C. J. (2011). The levels of inquiry model of science teaching. Journal of Physics Teacher Education Online, 6(2): 9-16.

[20] Zimrot, R., \& Ashkenazi, G. (2007). Interactive lecture demonstrations: a tool for exploring and enhancing conceptual change. Chemistry Education Research and Practice, 8(2): 197-211.

[21] West, R. W., \& Ogden, R. T. (1998). Interactive demonstrations for statistics education on the world wide web. Journal of Statistics Education, 6(3).

[22] Borg, W., \& M. Gall, M. (1983). Educational Research Forth Edition. New York: Longman.

[23] Yulianti, E., Al Husna, I. Y., \& Susilowati, S. (2018). The Role of Inquiry-Based Interactive Demonstration Learning Model on VIII Grade Students' Higher Order Thinking Skill. Journal of Science Education Research, 2(1): 35-38.

[24] Creswell, J. (2012). Educational research: planning, conducting, and evaluating quantitative and qualitative research. United States of America: Pearson Education.

[25] Meltzer, D. E. (2002). The relationship between mathematics preparation and conceptual learning gains in physics: A possible "hidden variable" in diagnostic pretest scores. American journal of physics, 70(12): 1259-1268.

[26] Suparno, P. (2013). Metodelogi Pembelajaran Fisika Kostruktivistik \& Menyenangkan. Yogyakarta: Universitas Sanata Dharma.

[27] BNSP. (2016). Salinan Lampiran Peraturan Menteri Pendidikan dan Kebudayaan No 22 Tahun 2016 tentang Standar Proses Pendidikan Dasar dan Menengah.

[28] Supriadi, D. (2000). Anatomi Buku Sekolah di Indonesia. Yogyakarta: Adi Cita.

[29] Krisnasanjaya, K., \& Muliastuti, L. (1997). Telaah Kurikulum 1994 dan Buku Teks I. Jakarta: Departemen Pendidikan dan Kebudayaan.

[30] Sulistyo, P. E., Suparmi, S., \& Sarwanto, S. Pengembangan Modul Fisika Berbasis Interactive Demonstration Untuk Meningkatkan Keterampilan Berpikir Kritis Dan Penguasaan Konsep Siswa SMA/MA Pada Materi Mekanika Fluida. Inkuiri: Jurnal Pendidikan IPA, 7(3): 455-469.

[31] Fakhrurrazi, F., Sajidan, S., \& Karyanto, P. (2019). Keefektifan Penggunaan Modul Sistem Gerak pada Manusia Berbasis Inkuiri Interactive Demonstration untuk Memberdayakan Keterampilan Berpikir Analitis Siswa. Jurnal Pendidikan: Teori, Penelitian, dan Pengembangan, 4(4): 478-483.

[32] Santyasa, I. W. (2007). Model-model pembelajaran inovatif. Universitas Pendidikan Ganesha.

[33] Al Husna, I. Y., Masykuri, M., \& Muzzazinah, M. (2019). "Using Inquiry-Interactive Demonstration Learning to Enhance Students' Learning Outcomes. International Journal of Education and Social Science Research, 2(6): 254-259.

[34] Azizah, R., Yuliati, L., \& Latifa, E. (2017). Kemampuan pemecahan masalah melalui pembelajaran interactive demonstration siswa kelas X SMA pada materi kalor. Jurnal Pendidikan Fisika dan Teknologi, 2(2): 55-60.

[35] Jauhariyah, M. N. R., Zaitul, Z., \& Indina, M. (2018, July). Learn Physics Using Interactive Demonstration to Reduce The Students' Misconceptions on Mechanical Wave. In Mathematics, Informatics, Science, and Education International Conference (MISEIC 2018). Atlantis Press.

[36] Davoudi, M. (2005). Inference generation skill and text comprehension. The Reading Matrix, 5(1): 106-123.

[37] Marzano, R. J. (2009). The art and science of teaching: Six steps to better vocabulary instruction. Educational leadership, 67(1): 83-84.

[38] Elbro, C., \& Buch-Iversen, I. (2013). Activation of background knowledge for inference making: Effects on reading comprehension. Scientific Studies of Reading, 17(6): 435-452. 
JIPF, Vol. 6 No. 1, January 2021

[39] Rose, C., \& Nicholl, M. J. (2012). Accelerated Learning for the 21st Century. London: Judy Piatkus.

[40] Jacobsen, D. A., Edgen, P., \& Kauchak, D. (2009). Methods for Teaching: Promoting Student Learning in K-12 Classrooms, 8th Edition. New Jersey: Prentice Hall.

[41] Abdi, A. (2014). The Effect of Inquiry-Based Learning Method on Students' Academic Achievement in Science Course. Universal journal of educational Research, 2(1): 37-41. 